\title{
The Influence of Concentration Chitosan of A Shell Snail to Lower Levels of BOD and COD on Waste Laundry
}

\author{
Karim Kasmudin ${ }^{\mathrm{a}, *}$, Fitria Fitria ${ }^{\mathrm{a}}$, \& A. Artiningsih ${ }^{\mathrm{b}}$ \\ ${ }^{a}$ Chemical Engineering Study Program, Bontang College of Industrial Technology, Indonesia \\ ${ }^{b}$ Department of Chemical Engineering, Faculty of Industrial Technology, Muslim University of Indonesia, Indonesia
}

\begin{abstract}
Disposal of laundry waste directly in the river is the cause of high river pollution. Laundry wastewater resulted in an increase in BOD and COD parameters so that it had a negative impact on ecosystem life. The coagulation process using chemicals can reduce BOD and COD parameters in wastewater but have negative effects on health. Chitosan from snail shells can be used as an alternative coagulant that is environmentally friendly because it contains about $70 \%-80 \%$ chitin. This study aims to synthesize chitosan bio-coagulants from snail shells and to test the effectiveness of snail shell chitosan in the treatment of laundry wastewater. Fourier Transform Infra-Red (FTIR) analysis showed that the deacetylation rate of chitosan obtained was $78.06 \%$. Coagulation was carried out on wastewater using variable concentrations and stirring speed. The results showed that the optimum dose of snail shell chitosan biocoagulant was at a concentration of $0.4 \%$. At this dose, the coagulant can bind to the most optimal contaminants so that it can reduce the BOD and COD values in laundry waste and the Fast Stirring Speed of 100 $\mathrm{rpm}$ is the optimum stirring speed because large speeds will produce excessive shear forces and prevent the desired floc arrangement.
\end{abstract}

Keywords: Laundry wastewater, chitosan, snails, coagulation.

Received: 8 November 2021

Revised: 16 January 2022

Accepted: 2 February 2022

\section{Introduction}

Laundry business is a service provider that provides clothes washing facilities. For those who are busy or lazy to wash, then laundry is an option to solve the problem. The development of society that is increasingly modern and practical thinking is growing, causin $\mathrm{g}$ laundry business businesses to appear everywhere, from small to large scale (Ardiyanto \& Yuantari, 2016). Laundry liquid waste contains several chemicals in detergent raw materials such as phosphate, surfactant, ammonia and nitrogen as well as dissolved solids, turbidity, BOD (Biological Oxygen Demands), and COD (Chemical Oxygen Demands). The presence of detergents in high concentrations and exceeding the quality standards that have been set in water bodies can cause cases of environmental pollution (Putri et al., 2015). Based on the Decree of the Governor of South Sulawesi Number 69 of 2010 the COD Quality Standard value given to the liquid waste of the detergent soap industry is $160 \mathrm{mg} / \mathrm{l}$ and the BOD Quality Standard is $75 \mathrm{mg} / \mathrm{l}$.

The methods used in efforts to control liquid waste pollution include physical, chemical and biological waste treatment or a combination thereof. Generally, chemical wastewater treatment is carried out by the coagulationflocculation process. Coagulation-flocculation is a process that involves physical and chemical processes. Chemical processes include coagulant mixing, ionization processes, compound binding and charge exchange. Mixing coagulants that are usually used are made from chemicals such as aluminum sulfate $\left(\mathrm{Al}_{2}\left(\mathrm{SO}_{4}\right)_{3} \cdot 14 \mathrm{H}_{2} \mathrm{O}\right)$ and Ferrie sulfate $\left(\mathrm{Fe}_{2}\left(\mathrm{SO}_{4}\right)_{3}\right)$ (Aulia et al., 2016). The application of chemicals in the coagulation process is not good for humans and the environment, where in the end the effluent from the coagulation-flocculation process will contain certain chemical elements that should not be discharged into the environment. Along with increasing human awareness of environmental health, natural coagulants have begun to be widely studied. One of the

\footnotetext{
* Corresponding author.

E-mail address: kasmudinkarim@gmail.com
} 
biocoagulants developed is chitosan derived from crustaceans, arthropods, gastrophoda, and others (Nugraheni et al., 2018).

The raw material for making chitosan is very abundant, one of which is snail shells. Snail shell waste is one source of natural ingredients rich in chitin which is easily available and available in large quantities as waste from restaurants that have not been utilized. Chitosan comes from organic materials and is a cation polyelectrolyte so that in the water treatment process it is very potential to be used as a natural coagulant and absorbent (Khairuni et al., 2017). The chitin content in snail shells can produce chitosan. Snail shells contain $70-80 \%$ chitin, so the snail shells can be used as a chitin producer (W. Wahyuni et al., 2016). Based on the above background, researchers are interested in conducting further research on the use of chitosan from golden snail shells to reduce BOD (Biological Oxygen Demands) and COD (Chemical Oxygen Demands) levels in laundry wastewater so as not to pollute the environment.

\section{Research Methods}

\subsection{Materials}

The materials used in this study were snail shells, Laundry Water Waste, $\mathrm{NaOCl}$ p.a. Merck, Acetic Acid p.a. Merck, $\mathrm{NaOH}$ p.a. Merck, $\mathrm{HCl}$ p.a. Merck, concentrated $\mathrm{H}_{2} \mathrm{SO}_{4}$ p.a. Merck and Aquades.

\subsection{Tools}

The tools used in this research are Magnetic stirrer, portable pH meter, analytical balance, beaker glass $1000 \mathrm{ml}$, beaker glass $250 \mathrm{ml}$, volumetric flask $10 \mathrm{ml}$, measuring cup, measuring pipette, volumetric flask $500 \mathrm{ml}$, stirrer, oven, sieve 120 mesh.

\subsection{Research Procedure}

a. Chitosan Making

\section{- Deproteination}

A total of 50 grams of snail shell powder was immersed in $3.5 \% \mathrm{NaOH}$ with a ratio of 1:10 (w:v) while stirring using a magnetic stirrer and heated at $65^{\circ} \mathrm{C}$ for 2 hours. Furthermore, the solids were filtered through a cloth filter and washed with distilled water until the $\mathrm{pH}$ was neutral and dried in an oven for 6 hours at $80^{\circ} \mathrm{C}$.

\section{- Demineralization}

The results of the deproteination were then immersed in $1 \mathrm{~N}$ concentrated $\mathrm{HCl}$ with a ratio of 1:15 (w/v) and stirred in a magnetic stirrer for 2 hours while heated at a temperature of $65^{\circ} \mathrm{C}$. then the solids were filtered and washed with distilled water until the $\mathrm{pH}$ was neutral and dried in an oven for 6 hours at $80^{\circ} \mathrm{C}$.

\section{- Deacetylation}

The results of the demineralization were then immersed in $50 \% \mathrm{NaOH}$ in a ratio of 1:10 and stirred while heated at $100^{\circ} \mathrm{C}$ for 2 hours. Then the results were filtered and washed with distilled water until the $\mathrm{pH}$ was neutral and oven for 6 hours at $80^{\circ} \mathrm{C}$.

\section{b. Coagulation Process}

Chitosan solution was made by dissolving $3 \mathrm{~g}$ dissolved in $100 \mathrm{ml}$ of $1 \%$ acetic acid. This solution was used for further research. Then $1 \mathrm{ml}, 2 \mathrm{ml}, 3 \mathrm{ml}$ and $4 \mathrm{ml}$ of chitosan solution were taken into a $10 \mathrm{ml}$ volumetric flask, then diluted with distilled water to the limit mark. Then obtained solutions of $0.1 \%, 0.2 \%, 0.3 \%$ and $0.4 \%$. Each was put into a $1000 \mathrm{ml}$ beaker which already contained laundry waste water.

Then the sample was stirred using a magnetic stirrer at speeds of $100 \mathrm{rpm}, 125 \mathrm{rpm}$ and $150 \mathrm{rpm}$, stirring was carried out for 1 minute followed by slow stirring at $50 \mathrm{rpm}$, stirring was carried out for 20 minutes and precipitation for 15 minutes on each sample. Analysis of wastewater parameters that have been treated by measuring each parameter is COD and BOD. 
c. Pollutant Parameter Analysis

Parameter analysis was carried out before and after going through the coagulation process. The purpose of this analysis is to determine the decrease in the concentration of pollutant load after undergoing processing with snail shell chitosan as coagulant. The research procedure reference is COD (SNI 6989.2-2009) and BOD (SNI 6989.72-2009).

\section{Results and Discussion}

\subsection{Chitosan Deacetylation Degree Value}

Figure 1 shows that the chitosan research results contain an $\mathrm{OH}$ - group with a peak of $3450 \mathrm{~cm}-1$ which is useful for removing the acetyl group from the acetamide group and producing an amine group (NH2) which has the ability to bind to reduce BOD and COD. The data in Figure 1 is used to calculate the degree of deacylation of chitosan.

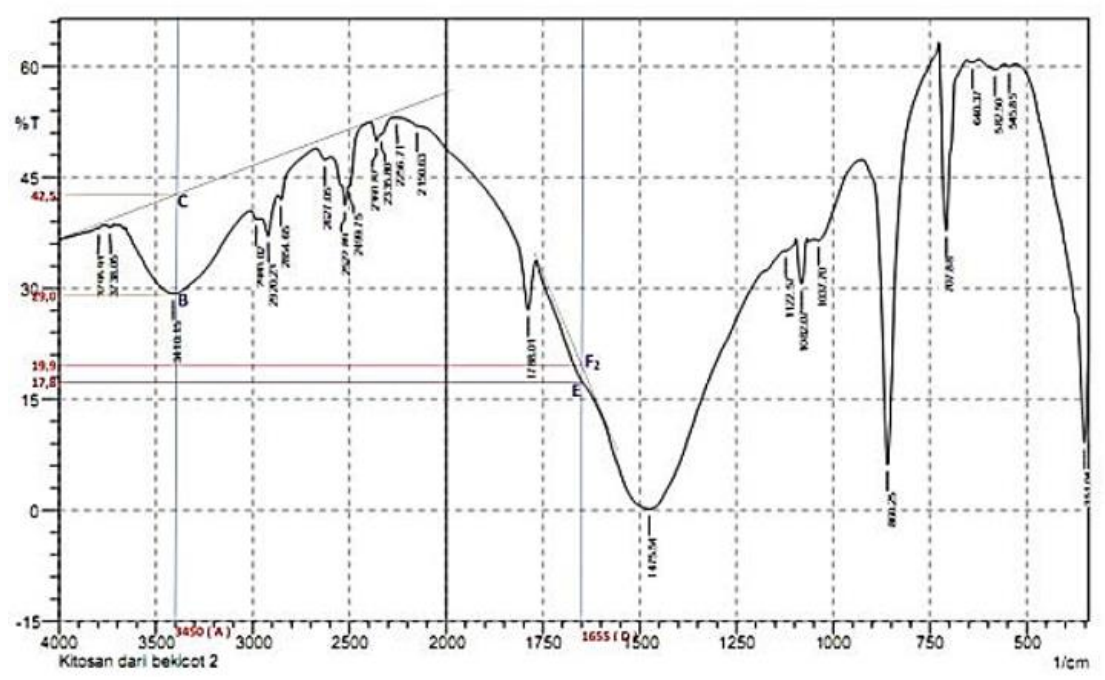

Fig. 1 Results of FTIR Chitosan Snail Shells

Based on the data in Figure 1, it is known that:
$\mathrm{DE}=19.9$
$\mathrm{DF} 1 \quad=17.8$
$\mathrm{AB} \quad=42.5$
$\mathrm{AC} \quad=29.0$

Baseline by Domszy and Roberts

$\mathrm{DD}=100-[(\mathrm{A} 1655 / \mathrm{A} 3450) \mathrm{X} 100 / 1.33]$

with $(\mathrm{A} 1655)$ amide $=\log 10(\mathrm{DF} 1 / \mathrm{DE})=-0.0484$

and $(\mathrm{A} 3450)$ hydroxyl $=\log 10(\mathrm{AC} / \mathrm{AB})=-0.1660$

So;

$$
\begin{aligned}
\mathrm{DD} & =100-[(-0.0484 /-0.1660) \times 100 / 1.33] \\
& =100-(0.2918 \times 75.1880) \\
& =100-(21.9385) \\
& =78.0616 \%
\end{aligned}
$$

Absorbance A1655 and A3450 were calculated using the Baseline equation by Domszy and Roberts (Sinardi et al., 2017). The result is that A1655 is -0.0484 while A3450 is -0.1660 . By using the Baseline equation by Domszy and Roberts, the degree of deacetylation (DD) of chitosan is $78.0616 \%$ and has met the standard in terms of the degree of deacetylation, more than $70 \%$ (Ifa et al., 2019). According to Wahyuni et al., 2016, chitosan which has a degree of deacetylation of more than $60 \%$ can be used as an adsorbent (S. Wahyuni et al., 2016). 


\subsection{Results of BOD and COD Analysis}

Laundry waste used in this study came from the Pampang Laundry Embun, Makassar city, which was taken at 16.00 WITA. The test was carried out 2 times. Table 1 follow the characteristics of waste from Pampang Laundry Embun, Makassar city.

Table 1. Characterization of waste from Pampang Laundry Embun

\begin{tabular}{cccc}
\hline Parameter & Unit & Test Result & Maximum Limit \\
\hline COD & $\mathrm{Mg} / \mathrm{L}$ & 910.06 & 160 \\
$\mathrm{BOD}$ & $\mathrm{Mg} / \mathrm{L}$ & 316.12 & 75 \\
\hline
\end{tabular}

\subsection{Efficiency of Snail Shell Chitosan as a Biocoagulant in Removing BOD (Biological Oxygen Demand)}

Liquid waste treatment using the coagulation-flocculation process can overcome the problem of BOD. In the coagulation process (rapid stirring) followed by slow stirring, all organic macroflocs will be combined and their weight will make it easier for these flocs to settle. Through the deposition process, all the flocs will descend by themselves by utilizing the force of gravity to form flocs. After being deposited, the presence of suspended (organic) particles will decrease in the water so that the availability of oxygen increases in the water so that the BOD value decreases (Setiawan et al., 2017). The efficiency of removing BOD concentration can be seen in Table 2.

Table 2. Efficiency of Removing BOD concentration of Each Variable

\begin{tabular}{cccc}
\hline $\begin{array}{c}\text { Solution } \\
\text { Concentration (\%) }\end{array}$ & \multicolumn{3}{c}{ BOD Concentration Each Round (mg/L) } \\
\hline 0 & $100 \mathrm{rpm}$ & $125 \mathrm{rpm}$ & $150 \mathrm{rpm}$ \\
\hline 0.1 & 316.12 & 316.12 & 316.12 \\
0.2 & 154.72 & 163.81 & 163.98 \\
0.3 & 107.35 & 134.74 & 134.61 \\
0.4 & 65.83 & 73.17 & 80.38 \\
\hline
\end{tabular}

Table 2 shows that each addition of the concentration can reduce the BOD level of the laundry water waste that is sampled. Efficiency of BOD removal due to the addition of snail shell chitosan dose concentration. If it is displayed in a graph, it can be seen as in Figure 2.

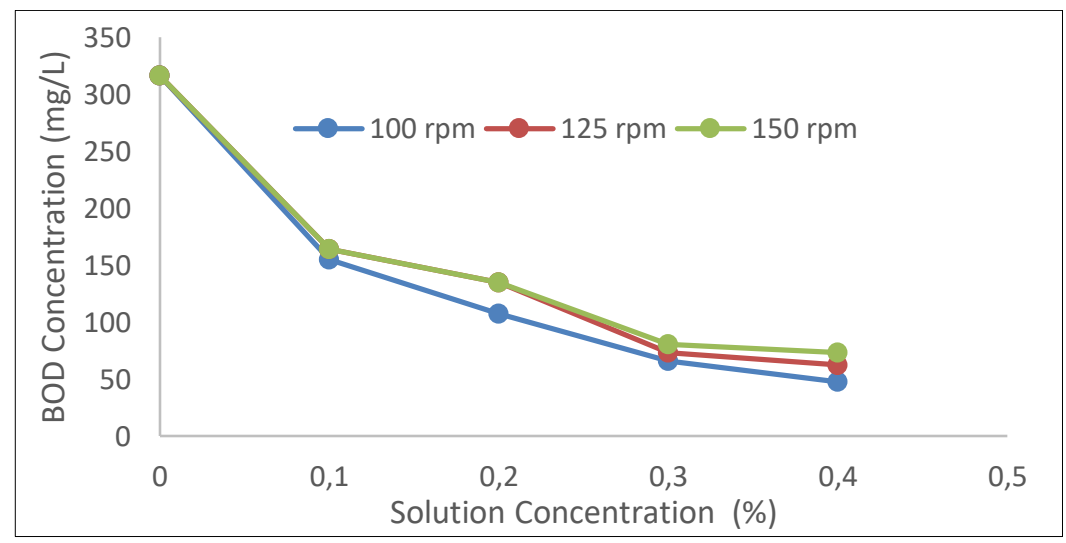

Fig. 2 Efficiency of Removing BOD concentration of Each Variable 
The highest efficiency in the sample with the addition of a dose concentration of $0.4 \%$ at $100 \mathrm{rpm}$ fast stirring with a BOD value of $47.50 \mathrm{mg} / \mathrm{L}$ where the BOD level of the Initial Sample is $316.12 \mathrm{mg} / \mathrm{L}$ or about $84,9741 \%$ decreased BOD levels sample. As for the lowest decrease value, that is, changing the concentration of $0.1 \%$ at 150 $\mathrm{rpm}$ with a BOD value of $163.98 \mathrm{mg} / \mathrm{L}$, where the BOD level of the Initial Sample is $316.12 \mathrm{mg} / \mathrm{L}$ or about $48.1273 \%$ of the decrease in concentration sample BOD.

In the coagulation process, the administration of coagulant is able to play a role through destabilization of suspended particles (which are organic) causing turbidity. The physical properties of these particles make them decompose due to the influence of stirring. Particles (which are organic) break down into smaller ones (microflocs) to finally form particles with larger sizes (macro-floc). With the reduced value of turbidity due to organic compounds, the BOD value will also decrease [10]. In addition, the faster the stirring will affect the reduced efficiency of BOD reduction which causes the BOD value to increase (Junaidi et al., 2020).

\subsection{Efficiency of Chitosan Snail Shells as Biocoagulants in Removal of COD (Chemical Oxygen Demand)}

Another parameter that can also be used as an estimator of organic waste pollution is COD. The COD value describes the total oxygen required to chemically oxidize organic matter, both those that can be degraded biologically (biodegradable) and those that are difficult to degrade (non-biodegradable) into $\mathrm{CO}_{2}$ and $\mathrm{H}_{2} \mathrm{O}$ (Purnama Sari \& Rusmini, 2017). COD removal efficiency can be seen in table 3.

Table 3. Efficiency of Removing COD concentration of Each Variable

\begin{tabular}{cccc}
\hline $\begin{array}{c}\text { Solution } \\
\text { Concentration (\%) }\end{array}$ & \multicolumn{3}{c}{ COD Concentration Each Round (mg/L) } \\
\hline 0 & $9100 \mathrm{rpm}$ & $125 \mathrm{rpm}$ & $150 \mathrm{rpm}$ \\
\hline 0.1 & 625.09 & 910.06 & 910.06 \\
0.2 & 335.39 & 839.79 & 831.79 \\
0.3 & 121.86 & 478.33 & 480.32 \\
0.4 & 88.40 & 180.99 & 193.28 \\
\hline
\end{tabular}

Table 3 shows that each addition of the concentration can reduce the COD level of the laundry water waste that is sampled. COD removal efficiency due to the addition of snail shell chitosan dose concentration. If it is displayed in a graph, it can be seen as in Figure 2.

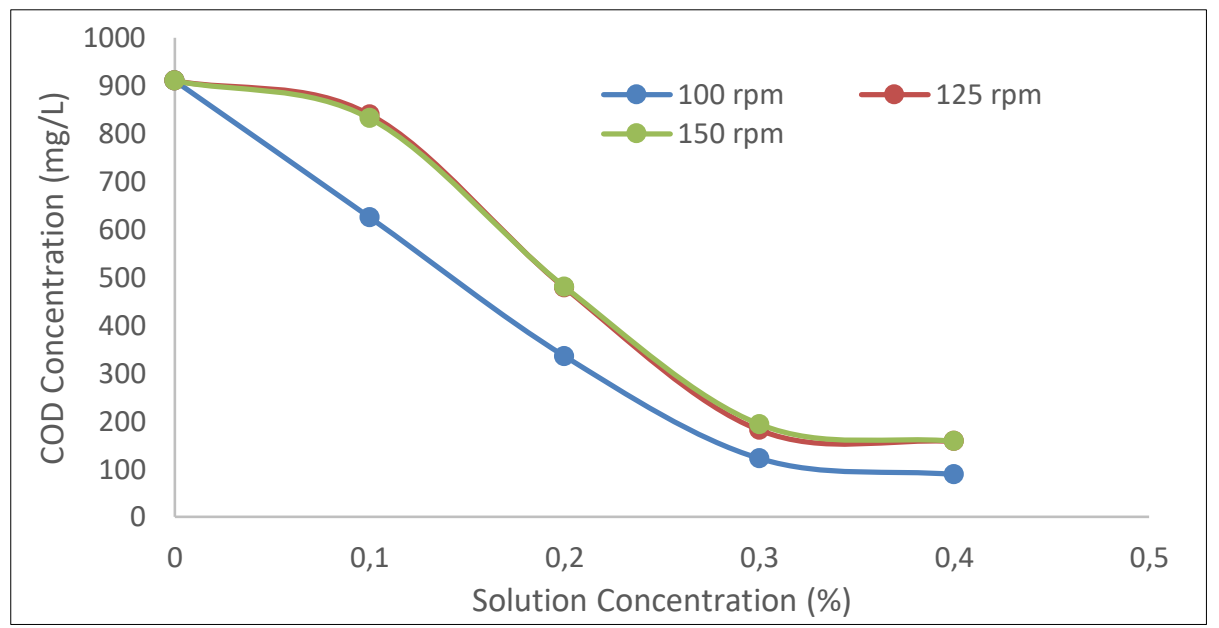

Fig 3. Efficiency of Removing COD concentration of Each Variable

The highest efficiency in the sample with the addition of a dose concentration of $0.4 \%$ at $100 \mathrm{rpm}$ fast stirring with a COD value of $88.40 \mathrm{mg} / \mathrm{L}$ where the COD content of the Initial Sample is $910.06 \mathrm{mg} / \mathrm{L}$ or about $90.2864 \%$ decreased levels of COD sample. As for the lowest reduction value, that is, changing the concentration of $0.1 \%$ at 
$150 \mathrm{rpm}$ fast stirring with a COD value of $831.79 \mathrm{mg} / \mathrm{L}$, where the initial COD level of the sample is $910.06 \mathrm{mg} / \mathrm{L}$ or about $8.6005 \%$ reduction rate sample COD.

The value of organic matter in water decreases after the coagulation-flocculation process. Organic substances are generally composed of the elements $\mathrm{C}, \mathrm{H}$ and $\mathrm{O}$ in some cases containing N, S, P. These elements form colloidal compounds in water so that with the coagulation-flocculating process these elements are deposited (Mahatmanti \& Sumarni, 2017). The decrease in COD concentration by the coagulant dose factor occurred because chitosan as a bio-coagulant is biological in nature which is able to bind or absorb suspended particles (which are organic) so that these particles are successfully deposited. The binding of these particles causes the charge to become unstable. This unstable particle charge causes the meeting of ions with different charges so that there is an attractive force. When particles with different charges attract each-other it will form particles with a larger size making it easier for them to settle in the form of flocs. After settling in the form of floc, the amount of oxygen in the water will increase again. The decrease in the number of suspended particles in the liquid waste increases so that the COD value decreases (Junaidi et al., 2020).

\section{Conclusion}

Based on the results of research that has been done, it can be concluded as follows:

1. The optimum dose of snail shell chitosan biocoagulant was at a concentration of $0.4 \%$. At this dose, the coagulant can bind to the most optimal pollutant so that it can reduce the BOD and COD values in Laundry waste.

2. Fast Stirring Speed $100 \mathrm{rpm}$ is the optimum stirring speed. The faster stirring speed produces an infinite shear force, if the speed is large it will produce excessive shear and prevent the desired floc arrangement.

3. Snail shell chitosan biocoagulant is able to act as a biocoagulant and this is proven by the efficiency produced by decreasing the concentration of BOD by $84.9741 \%$ and decreasing COD by $90,2864 \%$.

\section{Acknowledgments}

Thanks to Dr. Ir. Nurjannah, S.T., M.T., IPM. ASEAN Eng., as the head of the Chemical Engineering Operations Laboratory, Chemical Engineering Department, Faculty of Industrial Technology, Muslim University of Indonesian for his assistance in using all of these research tools.

Conflicts of Interest: The authors declare that they have no conflicts of interest to report regarding the present study.

Contribution: Karim Kasmudin: concept and design, data acquisition, data analysis / interpretation, drafting manuscript, critical revision of manuscript, statistical analysis. Fitriah: securing funding, admin, technical or material support, supervision, final approval. Andi Artiningsih: securing funding, admin, technical or material support, supervision, final approval.

\section{References}

Ardiyanto, P., \& Yuantari, M. G. C. (2016). Analisis Limbah Laundry Informal Dengan Tingkat Pencemaran Lingkungan. Jukung, 2(1), 1-12.

Aulia, Z., Sutrisno, E., \& Hadiwidodo, M. (2016). Pemanfaatan Limbah Cangkang Kepiting Sebagai Biokoagulan Untuk Menurunkan Parameter Pencemar Cod Dan Tss Pada Limbah Industri Tahu. Foreign Affairs, 5(2), $1-12$.

Ifa, L., Agus, M. A., Kasmudin, K., \& Artiningsih, A. (2019). Pengaruh Penambahan Volume Kitosan dari Cangkang Bekicot terhadap Penurunan Kadar Tembaga Air Lindi. Jurnal Teknik, 18(02), 109-113.

Junaidi, E., Siahaan, J., \& Hakim, A. (2020). Bioadsorben Salinitas Sederhana berbasis Limbah Lingkungan. Jurnal Pijar Mipa, 15(2), 165. https://doi.org/10.29303/jpm.v15i2.1625

Khairuni, M., Alfian, Z., \& Agusnar, H. (2017). Studi Penggunaan Kitosan Komposit CuO Sebagai Adsorben 
Untuk Menyerap Logam Besi ( Fe ), Mangan ( Mn ) Dan Seng ( Zn ) Pada Air Sungai Belawan. Jurnal Kimia Mulawarman, 14(2), 115-119.

Mahatmanti, F. W., \& Sumarni, W. (2017). Kajian Termodinamika Penyerapan Zat Warna Indikator Metil Oranye (MO) dalam Larutan Air oleh Adsorben Kitosan. Jurnal Kimia Sains Dan Aplikasi, 6(2), 13-18. https://doi.org/10.14710/jksa.6.2.13-18

Nugraheni, D. T., Sudarno, \& Hadiwidodo, M. (2018). Cangkang Udang Sebagai Biokoagulan Untuk Penyisihan Turbidity, TSS, BOD, Dan COD Pada Pengolahan Air Limbah Farmasi PT. Phapros Tbk, Semarang. Journal of Visual Languages \& Computing, 11(3), 55.

Purnama Sari, L., \& Rusmini. (2017). Pemanfaatan Kitosan dari Cangkang Kerang Simping sebagai Penjernih Air Sumur. UNESA Journal of Chemistry, 6(1), 64-67.

Putri, D., Joko, T., \& Dewanti, N. (2015). Kemampuan Koagulan Kitosan Dengan Variasi Dosis Dalam Menurunkan Kandungan Cod Dan Kekeruhan Pada Limbah Cair Laundry (Studi Pada Rahma Laundry, Kecamatan Tembalang, Kota Semarang). Jurnal Kesehatan Masyarakat Universitas Diponegoro, 3(3), 711722.

Setiawan, Y., Marwah, \& Meicahayanti, I. (2017). Pemanfaatan Kitosan Limbah Kulit Udang Untuk Penurunan Parameter BOD dan COD Limbah Cair Tekstil. Jurnal Teknologi Lingkungan, 1(02), 15-19.

Sinardi, S., Fajar, U., \& Iryani, A. S. (2017). Kitosan sebagai Bahan Antibakteri Alternatif dalam Formulasi Gel Pembersih Tangan. Prosiding Seminar Nasional Fakultas Teknik UNIFA Makassar, I(November). https://doi.org/10.13140/RG.2.2.21277.26081

Wahyuni, S., Siswanto, \& Damayanti. (2016). Penggunaan membran kitosan untuk penurunan COD dan BOD limbah cair kelapa sawit. Menara Perkebunan, 84(5), 21-27.

Wahyuni, W., Ridhay, A., \& Nurakhirawati, N. (2016). Pengaruh Waktu Proses Deasetilasi Kitin Dari Cangkang Bekicot (Achatina Fulica) Terhadap Derajat Deasetilasi. Kovalen, 2(1). 